\title{
ECONOMIC ACTIVITIES INFLUENCE MODELS ON THE TRAFFIC FLOWS IN BULGARIAN SEAPORTS
}

\author{
Emil Jelezov \\ "Todor Kableshkov" University of Transport, Sofia, Bulgaria \\ Gergana Kirilova \\ “Todor Kableshkov" University of Transport, Sofia, Bulgaria
}

CMESTE

JEL Category: L92, 018, R41

\begin{abstract}
The article presents analysis, assessment, and simple linear regression models of the basic economic activities impact on the volume of the cargo traffic processed in maritime ports of national importance in the Republic of Bulgaria. Dependencies between the industrial development trends and the turnover of the ports Varna and Burgas per main freight groups and directions (import, export and transit) are considered based on correlation and regression analysis. The trends of industry development are represented by industrial production indices by economic activities, classified according to the Statistical Classification of Economic Activities in the European Community (NACE). Trends in cargo turnover changes in ports are represented by indices of the physical volume of processed goods in the ports of Varna and Burgas. An assessment of the strength and directions influence of industry on the maritime cargo turnover of the seaports is made by defining the coefficients of a simple (one-factor) linear correlation between the industrial output indices by economic activity and port turnover load indexes. Verification of the statistical significance of the results and the determination of the linear models applicable for the predicted purposes was made by the F-test.
\end{abstract}

Keywords: national maritime ports, freight transport, basic economic activities, correlations between the industrial development trends and the turnover of the ports

\section{INTRODUCTION}

The national ports of Varna and Burgas are of great importance for Bulgaria. Around $75 \%$ of the import and over $70 \%$ of the export volumes of goods are handled at these two ports. For the period 2007 - 2015 the average annual freight

Address of the corresponding author:

Emil Jelezov

童”= ejelezov@abv.bg turnover of both ports amounts at more than 26 million tons, with a slight tendency towards increasing (Table 1).

The freight turnover at the ports is highly influenced by a number of economic, social and political factors. The industrial development is considered the basic factor influencing the generation of freight flows at ports, but the influence of different economic activities is not equal in terms of strength and direction. 
Table 1. Annual freight turnover at sea ports

\begin{tabular}{|c|c|c|c|}
\hline \multirow{2}{*}{ Year } & $\begin{array}{c}\text { Total for } \\
\text { the ports in } \\
\text { Varna port } \\
\text { area }\end{array}$ & $\begin{array}{c}\text { Total for } \\
\text { the ports in } \\
\text { Burgas } \\
\text { port area }\end{array}$ & $\begin{array}{c}\text { Total for } \\
\text { the sea } \\
\text { ports }\end{array}$ \\
\cline { 2 - 4 } (tonnes) & (tonnes) & (tonnes) \\
\hline 2007 & 9314444 & 16179168 & 25493613 \\
\hline 2008 & 11070385 & 16065294 & 27135679 \\
\hline 2009 & 8871575 & 13400229 & 22271803 \\
\hline 2010 & 10558008 & 12873257 & 23431265 \\
\hline 2011 & 12061074 & 13595515 & 25656589 \\
\hline 2012 & 11690991 & 14971965 & 26662955 \\
\hline 2013 & 13592082 & 15953432 & 29545514 \\
\hline 2014 & 12178285 & 15792103 & 27970389 \\
\hline 2015 & 11691898 & 16220651 & 27912548 \\
\hline
\end{tabular}

Source: "Integrated Transport Strategy for the period until 2030

The presented analysis identifies economic activities with considerable influence over the freight turnover in the ports of Varna and Burgas from statistical point of view. Adequate uni-factor regression models of their influence over the port freight turnover are established, applicable to the forecasting purposes.

\section{OBJECTIVES}

The main objectives of the analysis are as follows:

- determination of the existence of correlation between the economic activities and the freight turnover in the ports of Varna and Burgas;

- evaluation of the strength, ranging and determining the direction of influencing the port freight turnover by the economic activities;

- determination of regression equations of statistically significant dependencies and construction of their single-factor regression models.

\section{METHODOLOGY}

The dependencies between the industrial development tendencies per economic activities and the freight turnover of Port Varna and Port Burgas have been traced by the options import, export and transit during the period 2007-2015.

The industrial development tendencies are presented by statistical data quoted by the
Bulgarian National Statitical Institute concerning the industrial indexes per economic activities classified according to the Statistical Classification of Economic Activities in the European Community (NACE).

The tendencies of changing the ports' freight turnover are presented by indexes, determined according to the data of the physical volume of the import, export and transit goods handled at the ports.

Table 2. Factor variables

\begin{tabular}{|c|c|}
\hline$X$ & Industry total \\
\hline$X B$ & Mining and quarrying \\
\hline XB5 & Mining of coal and lignite \\
\hline$X B 7$ & Mining of metal ores \\
\hline$X B 8$ & Other mining and quarrying \\
\hline$X C$ & Manufacturing \\
\hline$X C 10$ & Manufacture of food products \\
\hline$x C 11$ & Manufacture of beverages \\
\hline$x C 12$ & Manufacture of tobacco products \\
\hline$X C 13$ & Manufacture of textiles \\
\hline$X C 14$ & Manufacture of wearing apparel \\
\hline$X C 15$ & Manufacture of leather and related products \\
\hline XC16 & $\begin{array}{l}\text { Manufacture of wood and of products of } \\
\text { wood and cork, except furniture; } \\
\text { manufacture of articles of straw and plaiting } \\
\text { materials }\end{array}$ \\
\hline$X C 18$ & Printing and reproduction of recorded media \\
\hline XC19 & $\begin{array}{l}\text { Manufacture of coke and refined petroleum } \\
\text { products }\end{array}$ \\
\hline XC20 & $\begin{array}{l}\text { Manufacture of chemicals and chemical } \\
\text { products }\end{array}$ \\
\hline$X C 21$ & $\begin{array}{l}\text { Manufacture of basic pharmaceutical } \\
\text { products and pharmaceutical preparations }\end{array}$ \\
\hline$x C 22$ & Manufacture of rubber and plastic products \\
\hline$X C 23$ & $\begin{array}{l}\text { Manufacture of other non-metallic mineral } \\
\text { products }\end{array}$ \\
\hline$X C 24$ & Manufacture of basic metals \\
\hline XC25 & $\begin{array}{l}\text { Manufacture of fabricated metal products, } \\
\text { except machinery and equipment }\end{array}$ \\
\hline$X C 26$ & $\begin{array}{l}\text { Manufacture of computer, electronic and } \\
\text { optical products }\end{array}$ \\
\hline$X C 27$ & Manufacture of electrical equipment \\
\hline XC28 & $\begin{array}{l}\text { Manufacture of machinery and equipment } \\
\text { n.e.c. }\end{array}$ \\
\hline XC29 & $\begin{array}{l}\text { Manufacture of motor vehicles, trailers and } \\
\text { semi-trailers }\end{array}$ \\
\hline XC30 & Manufacture of other transport equipment \\
\hline$X C 31$ & Manufacture of furniture \\
\hline XC32 & Other manufacturing \\
\hline$x C 33$ & $\begin{array}{l}\text { Repair and installation of machinery and } \\
\text { equipment }\end{array}$ \\
\hline
\end{tabular}


The estimation of the industrial influence over the ports' freight turnover is worked out through determining co-efficients of simple (uni-factor) linear correlation between the indexes of change of traffic and the indexes of freight turnover change.

The correlations between the Factor variables are studies (economic activities), listed in Table 2 and Dependent variables (directions of traffic flows), shown in Table 3 are studied.

Table 3. Dependent variables

\begin{tabular}{|c|c|c|c|c|c|}
\hline \multicolumn{4}{|c|}{ Dependent variables } \\
\hline \multicolumn{3}{|c|}{ Port Varna } & \multicolumn{3}{c|}{ Port Burgas } \\
\hline import & export & transit & import & export & transit \\
\hline Y1 & Y2 & Y3 & Y4 & Y5 & Y6 \\
\hline
\end{tabular}

The degree of determination of the variables dependent on the factor variables is determined by the coefficients of determination (R-squared).

To assess the strength of influence and the degree of determination of the variables, the scales shown in Table 4 have been applied.

Table 4. Rating scales

\begin{tabular}{|l|l|}
\hline \multicolumn{1}{|c|}{ Correlation strength } & \multicolumn{1}{|c|}{ Determination degree } \\
\hline $0.3<\mathrm{R}<0.5$ - moderate & $0.1<\mathrm{R}^{2}<0.25$ - moderate \\
\hline $\begin{array}{l}0,5<\mathrm{R}<0,7- \\
\text { considerable }\end{array}$ & $\begin{array}{l}0.25<\mathrm{R}^{2}<0.49- \\
\text { considerable }\end{array}$ \\
\hline $0.7<\mathrm{R}<0,9$ - high & $0.49<\mathrm{R}^{2}<0.81$ - high \\
\hline $0.9<\mathrm{R}<1.0$ - very high & $0.81<\mathrm{R}^{2}<1$ - very high \\
\hline
\end{tabular}

The verification of results has been tested through F-test (Fisher's citerion) at a confidence interval $\alpha=0.05$. The calculated value of Fcr (Critical Value of the F Distribution) is 5.987 .

Statistically significant are considered the dependencies, for which the statistical tests show values bigger than the critical $(\mathrm{F}>\mathrm{Fcr})$. The null hypothesis, defined as accidental is rejected for these dependencies.

For the dependencies selected as statistically significant, the parameters of the linear regression equations are determined, and one-factor regression models are constructed.

The algorithm for estimating and determining statistically significant and adequate for the purposes of forecasting single factor linear regression models of the industrial influence on port freight turnover are presented on Figure 1.

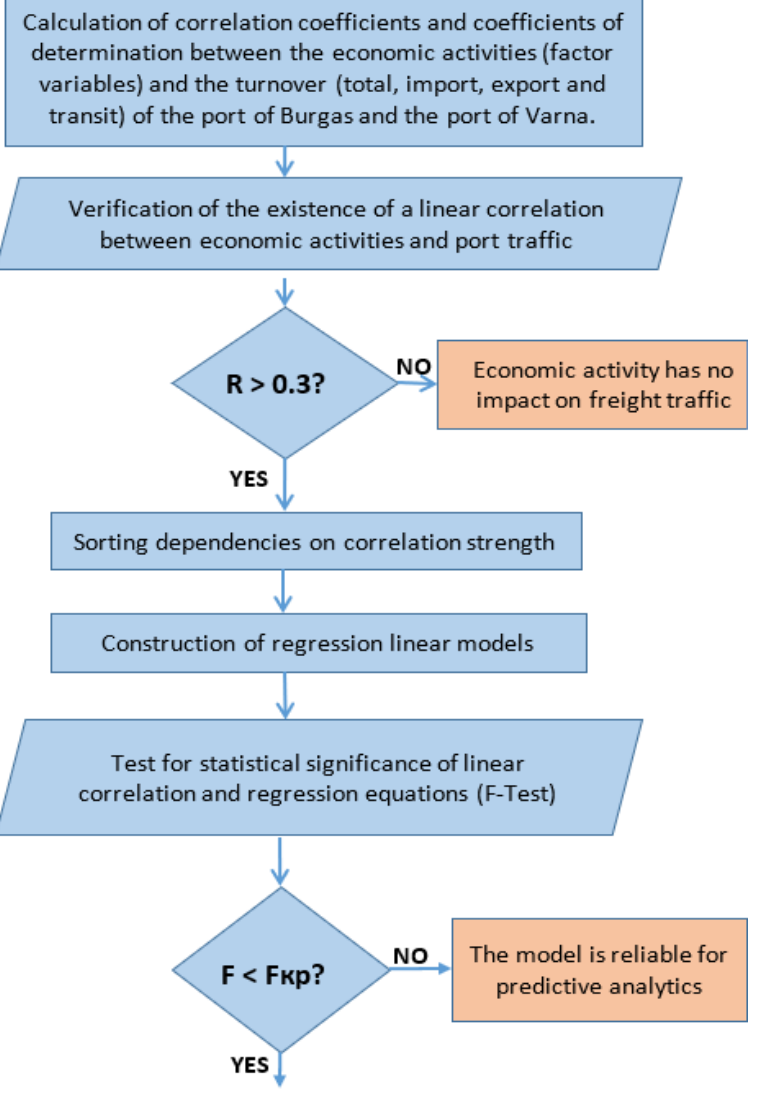

The model is applicable for port traffic forecasting

Fig. 1 Algorithm for evaluation and determination of statistically significant linear regression models

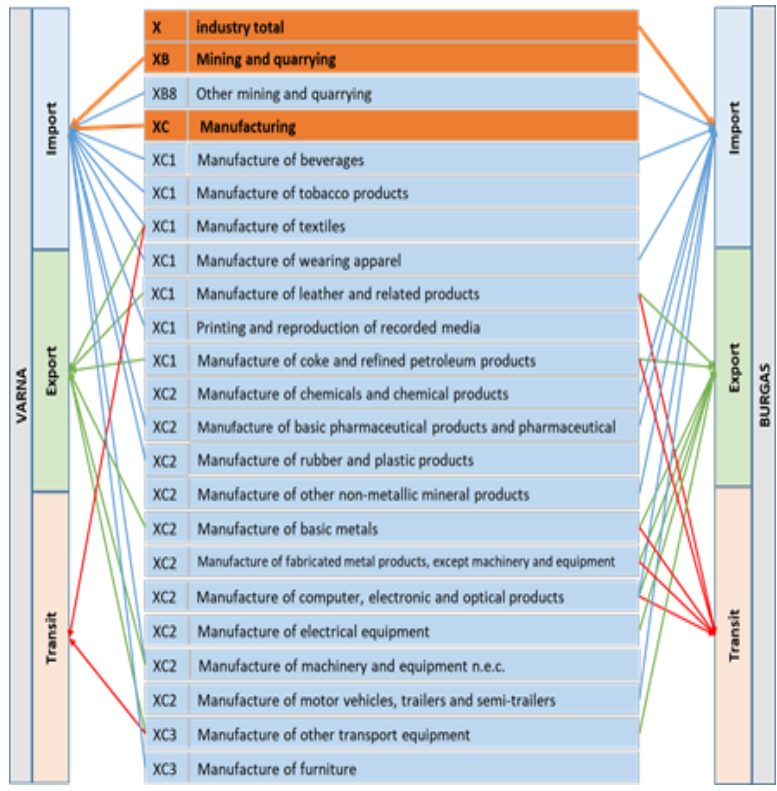

Fig. 2 Statistically significant dependencies

\section{RESULTS AND DISCUSSIONS}

Figure 2 represents schematically the identified statistically significant correlations between 
economic activities and the import, export and transit freight turnover of ports.

The linear one-factor regression models of statistically significant dependencies are applicable for the purposes of forecasting.
The imports in the Port of Varna is influenced by 12 of the studied economic activities, while the imports in the port of Burgas is influenced by 9 of them (Figures 3 and 4 ).

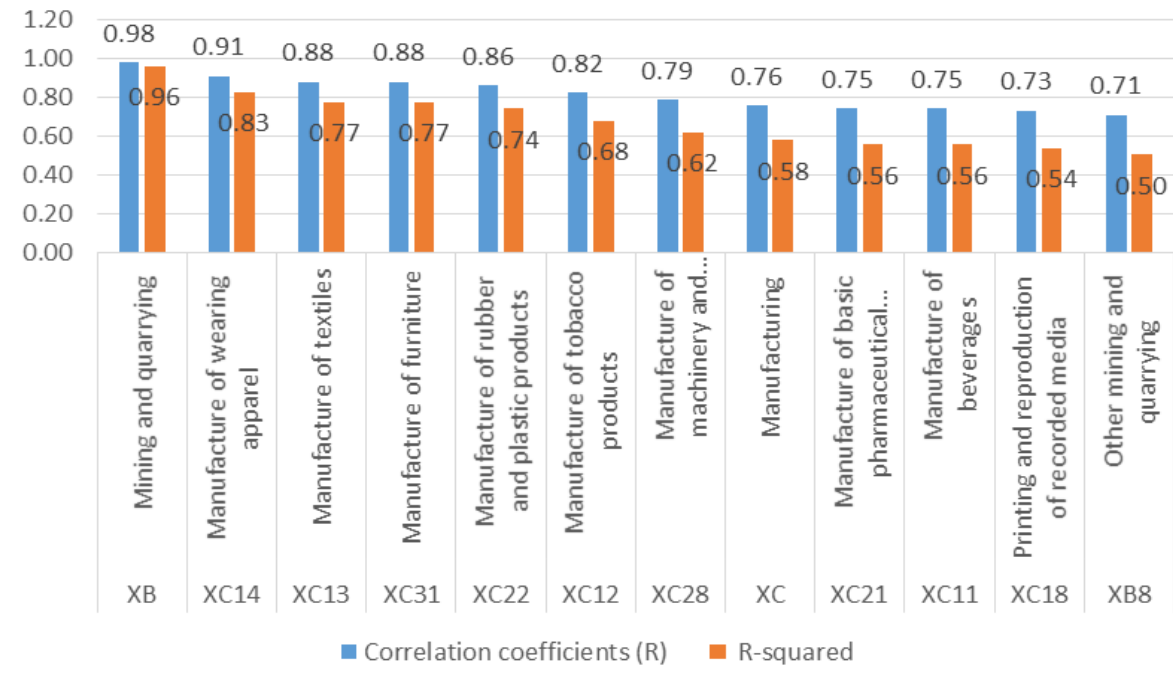

Fig. 3 Statistically significant dependencies for the import of the port of Varna

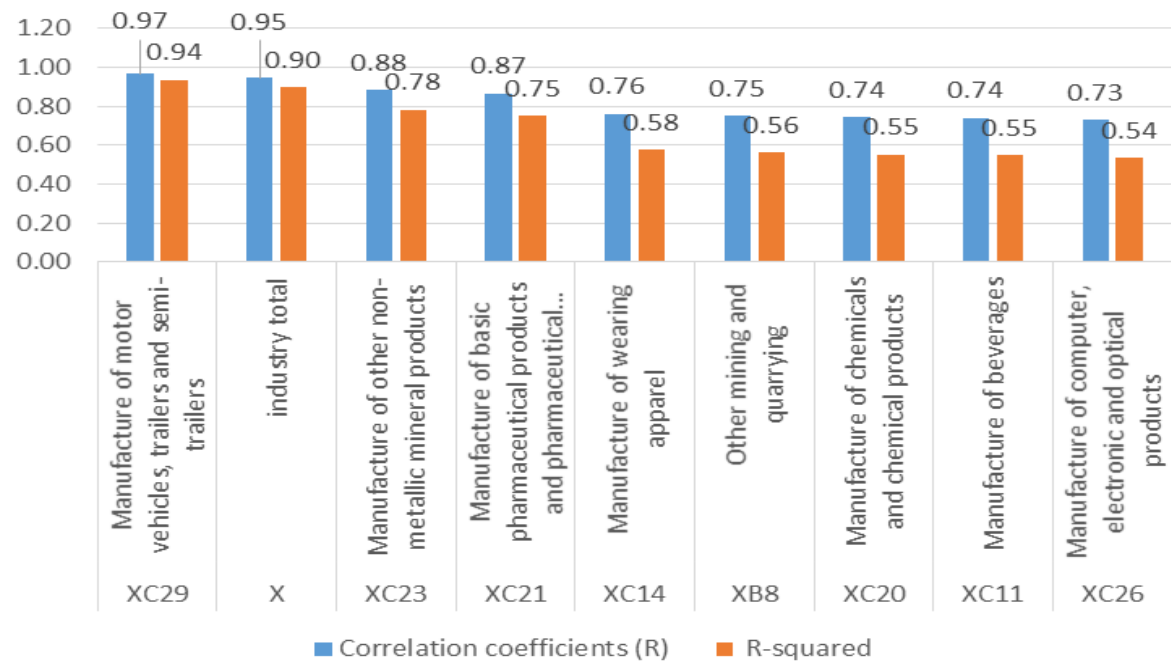

Fig. 4 Statistically significant dependencies for the import of the port Burgas industry total Burgas import

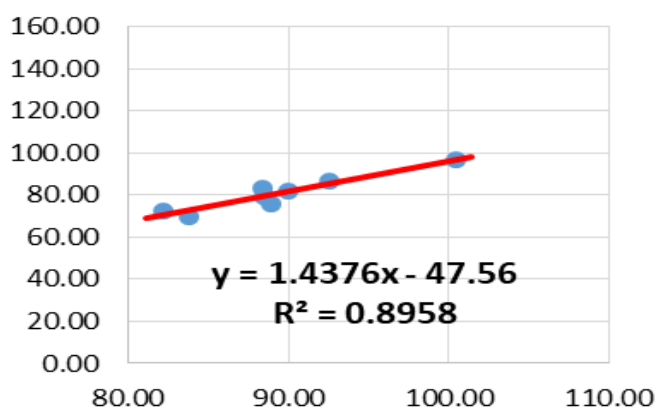

Fig. 5 Regression model of the industrial influence over the imports at the Port of Burgas
The influence of the industry as a whole over the imports through the Port of Burgas can be represented by the linear one-factor model on Figure 5.

Through linear one-factor models the dependencies between the imports through the port of Varna on one hand and the mining and processing industries on the other hand can also be presented (Figure 6) 
Mining and quarrying- Varna import

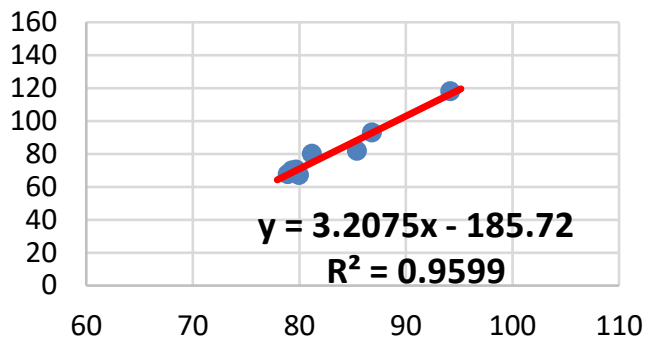

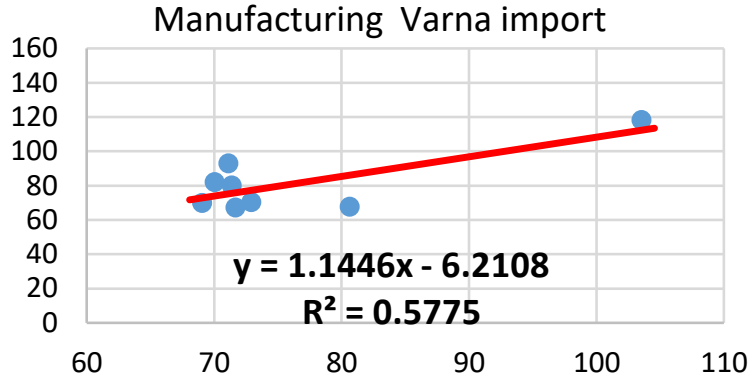

Fig. 6 Regression models of the imports through the Port of Varna

The imports in both ports are influenced by the economic activities "Other mining and quarrying", "Manufacture of beverages", "Manufacture of wearing apparel" and "Manufacture of basic

Other mining and quarrying - Varna

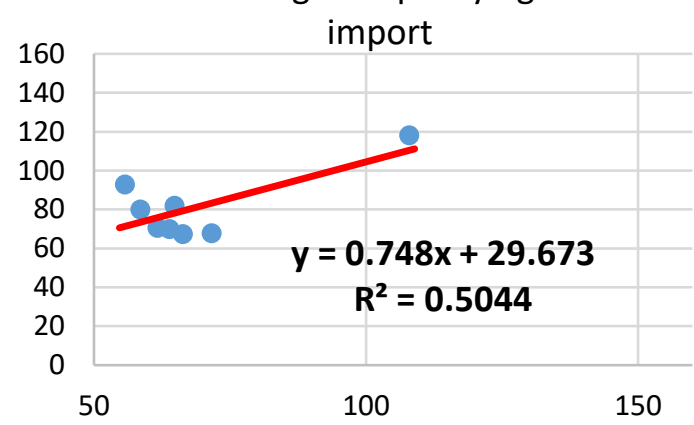

Manufacture of beverages- Varna import

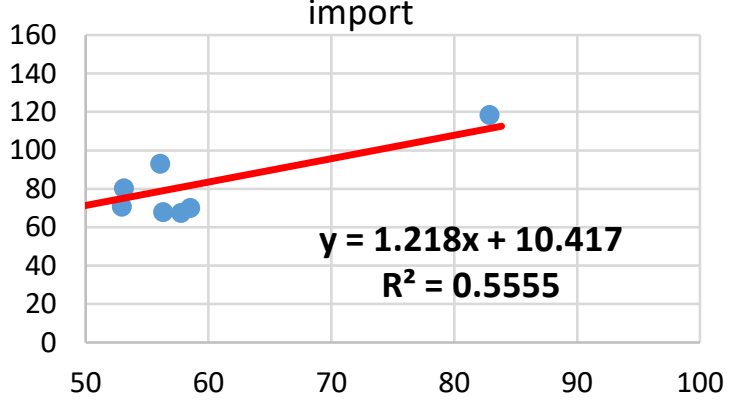

Manufacture of wearing apparel Varna import

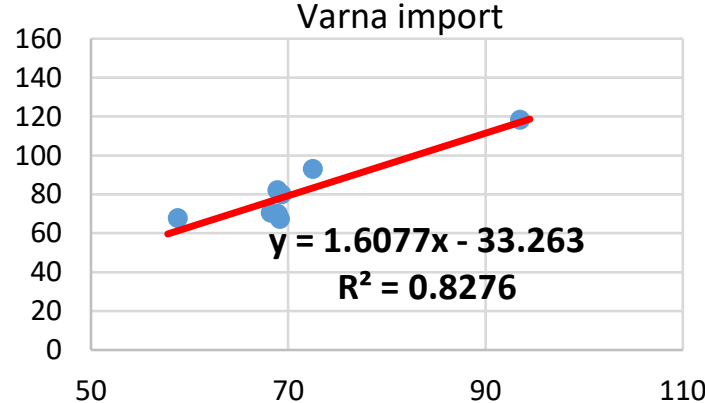

pharmaceutical products and pharmaceutical preparations". The regression models of those dependencies are presented on Figure 7.

Other mining and quarrying - Burgas

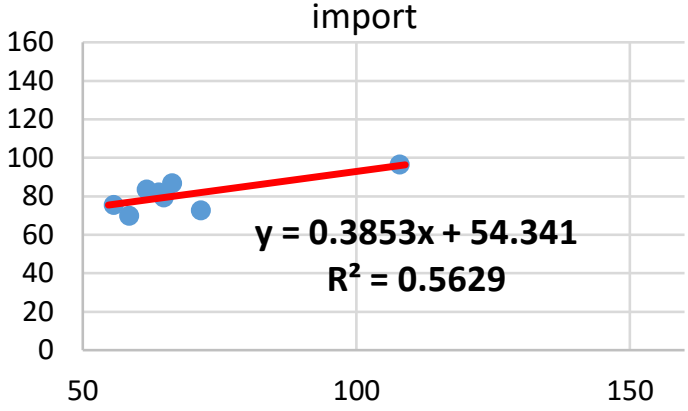

Manufacture of beverages- Burgas import

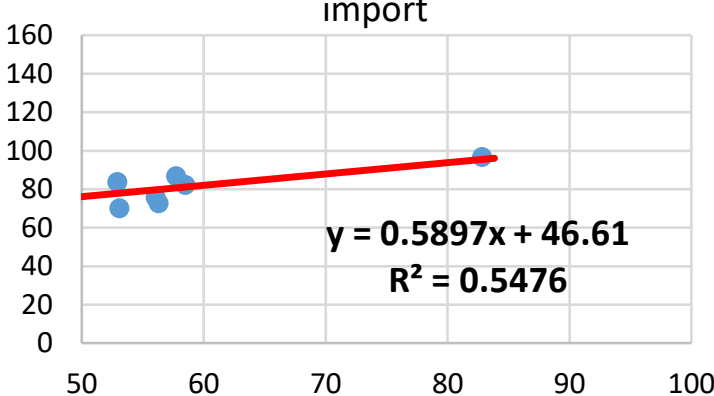

Manufacture of wearing apparel Burgas import

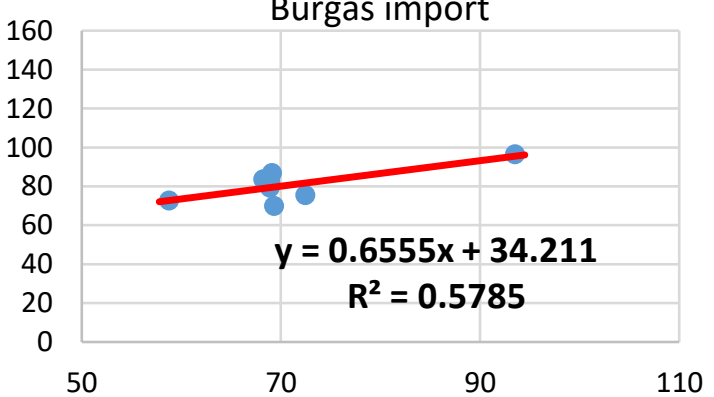

Fig. 7 Regresson models of dependencies of the imports in the Port of Varna and Port of Burgas on the basic factors (Continuation on the next page) 
Manufacture of basic pharmaceutical products and pharmaceutical

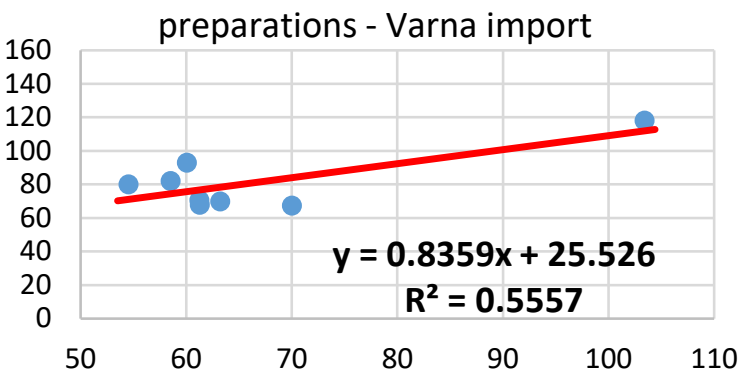

Manufacture of basic pharmaceutical products and pharmaceutical preparations - Burgas import

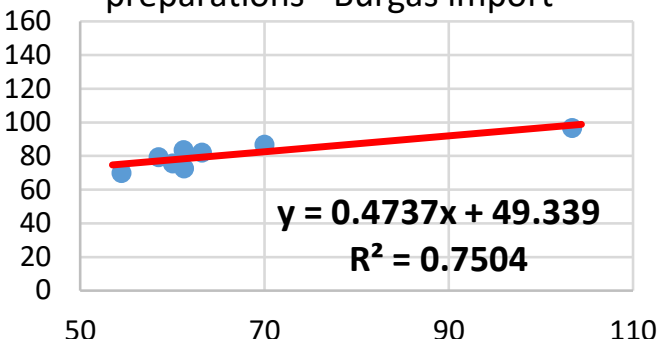

Fig. 8 Regresson models of dependencies of the imports in the Port of Varna and Port of Burgas on the basic factors

Specific factors influencing the imports of the Port of Varna are the following economic activities:

- Manufacture of tobacco products;

- Manufacture of textiles;

- Printing and reproduction of recorded media;

Manufacture of tobacco products- Varna import

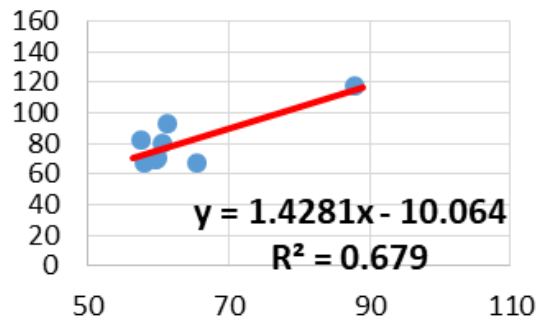

Printing and reproduction of recorded media - Varna import

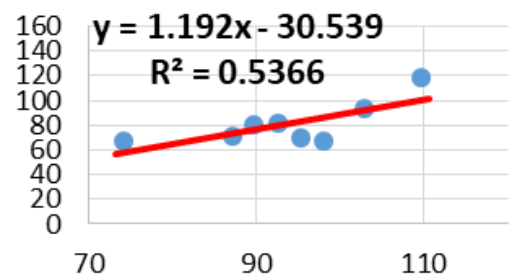

Manufacture of machinery and equipment n.e.c.- Varna

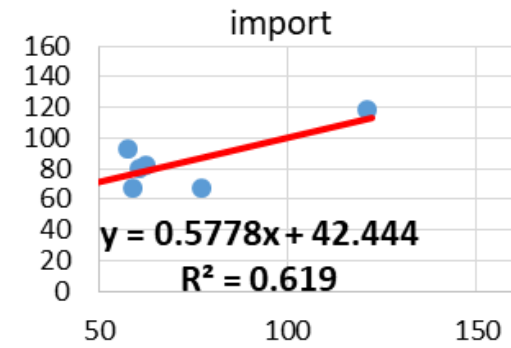

- Manufacture of rubber and plastic products;

- Manufacture of machinery and equipment n.e.c.; - Manufacture of furniture.

The regression models of those dependencies and their equations are presented on Figure 8.

Manufacture of textiles-

Varna import

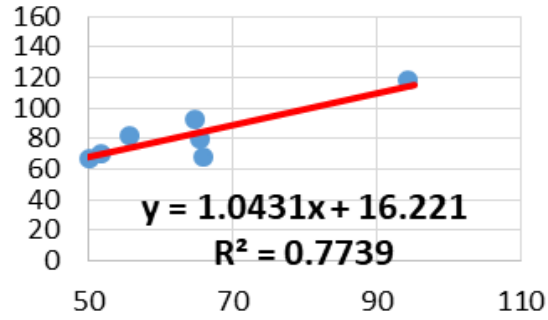

Manufacture of rubber and plastic products - Varna import

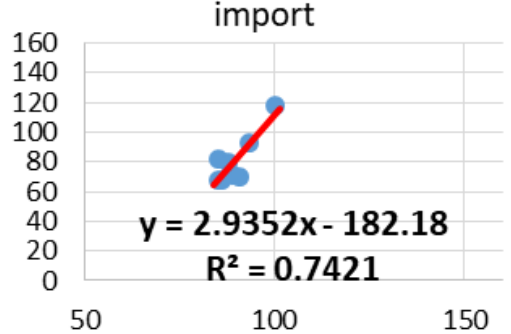

Manufacture of furnitureVarna import

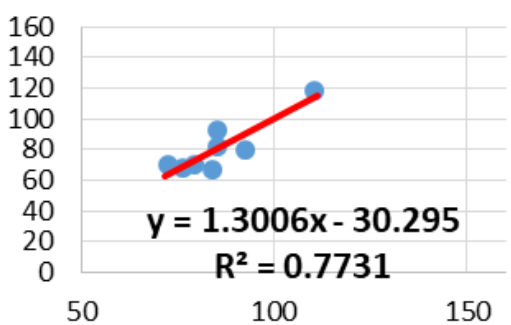

Fig. 9 Regression models of the dependencies between the imports in the Port of Varna and specific factors 
Specific factors, influencing the imports in the Port of Burgas are:

- Manufacture of chemicals and chemical products;

- Manufacture of other non-metallic mineral products;

Manufacture of chemicals and chemical products-

Burgas import

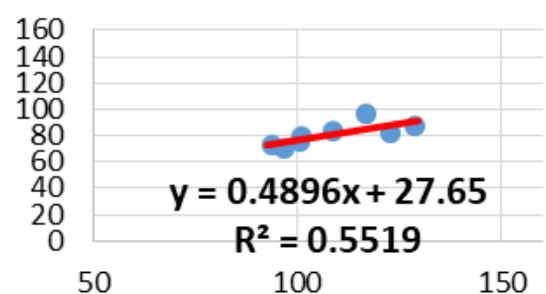

Manufacture of computer, electronic and optical products - Burgas import

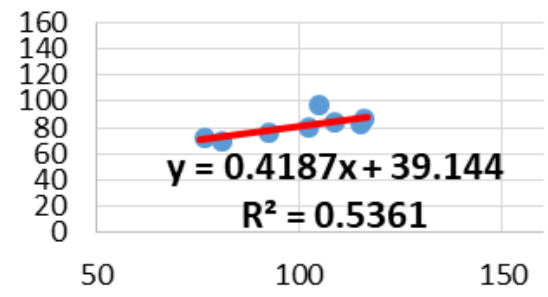

- Manufacture of computer, electronic and optical products;

- Manufacture of motor vehicles, trailers and semi-trailers.

The regression models of those dependencies and their equations are presented on Figure 9.

Manufacture of other nonmetallic mineral products-

Burgas import

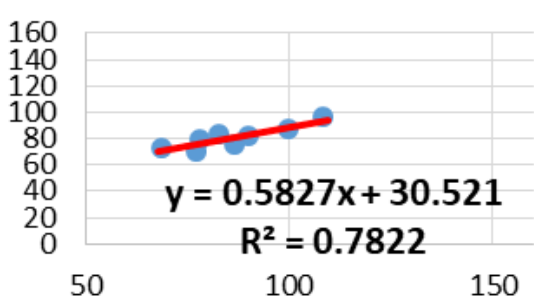

Manufacture of motor vehicles, trailers and semitrailers- Burgas import

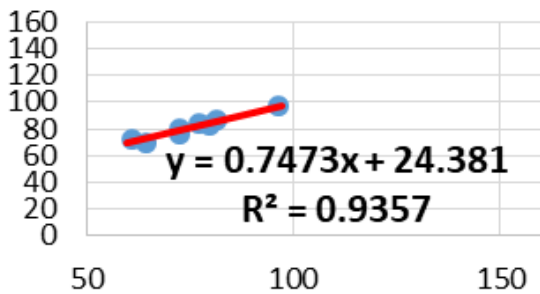

Fig. 10 Regression models of the dependencies between the imports in the Port of Burgas and specific factors

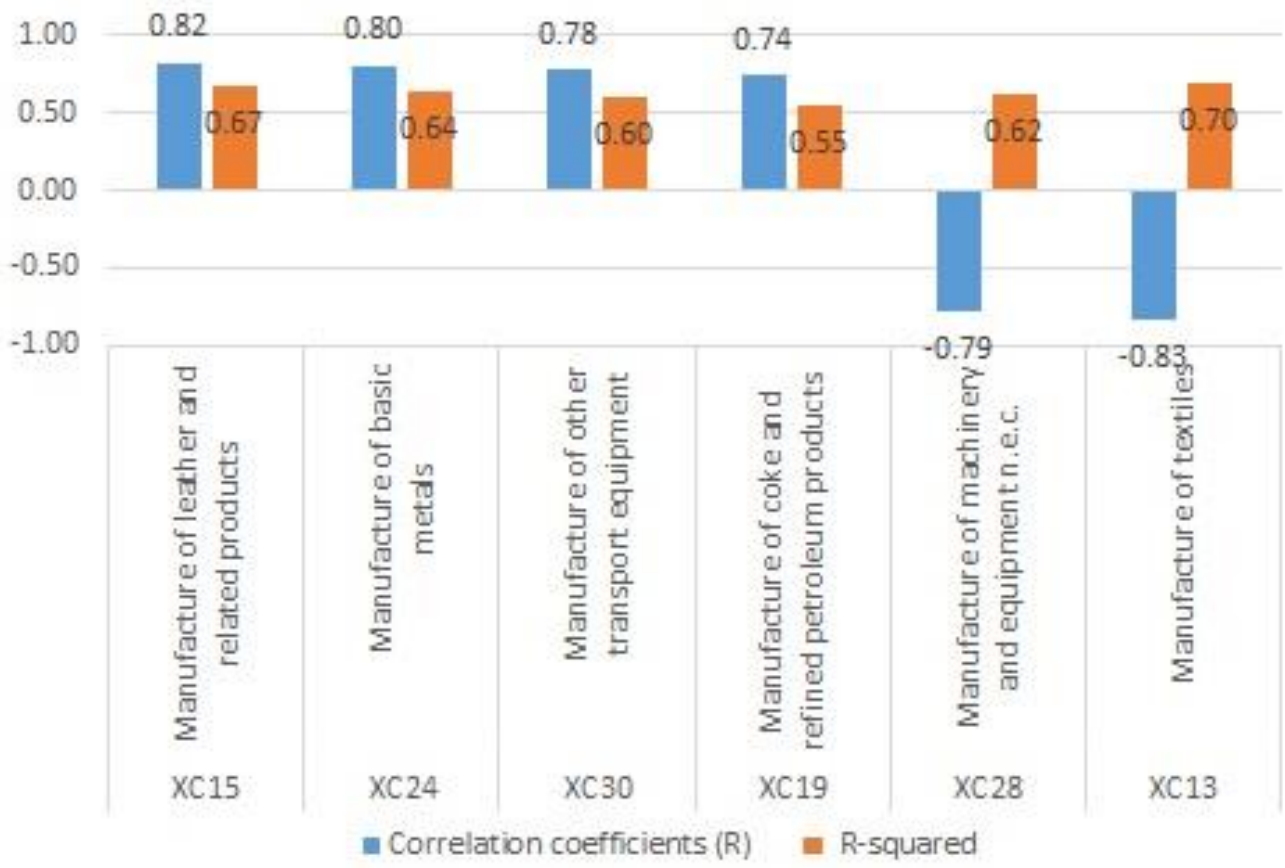

Fig. 11 Statistically significant dependencies for the export of the port of Varna 


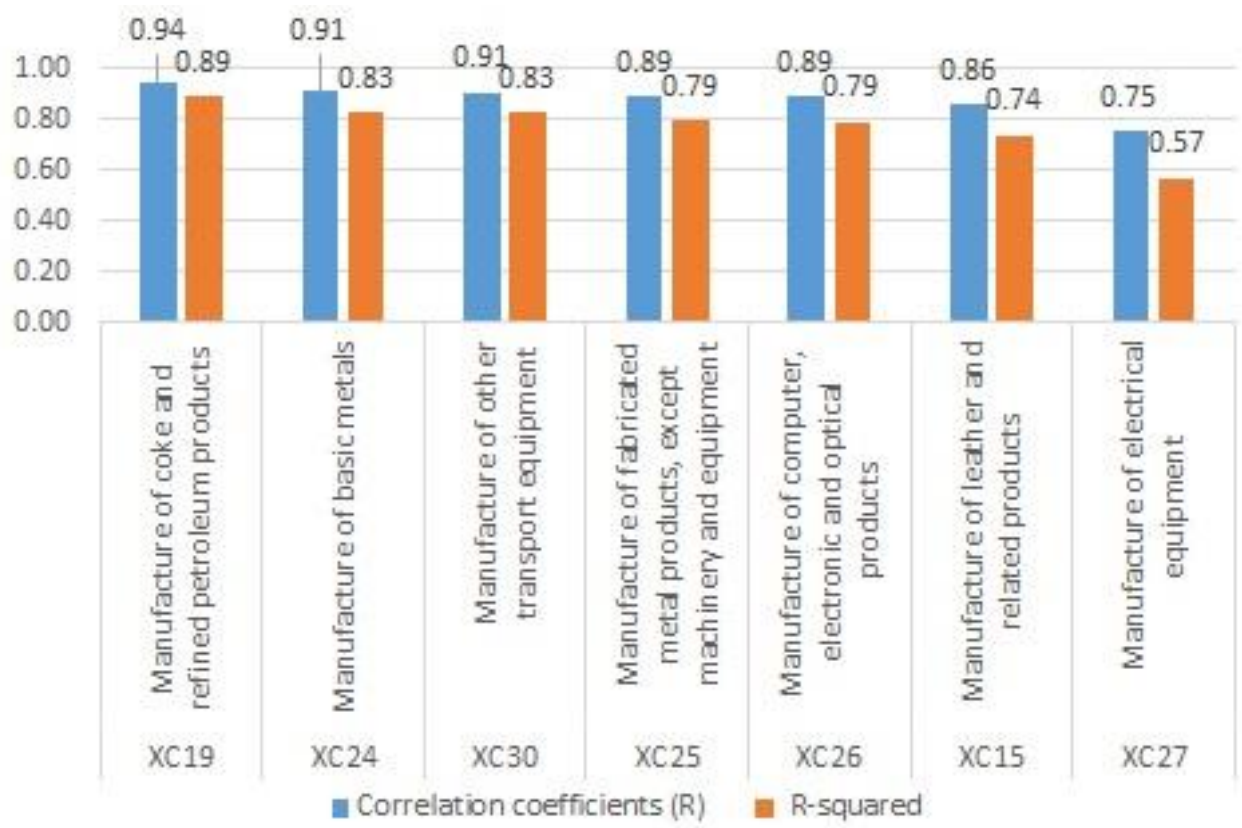

Fig. 12 Statistically significant dependencies for the export of port Burgas

The freight turnover for exports through the Port Varna and the Port of Burgas is highly influenced by 8 economic activities (Figures 10 and 11).

The freight turnover for exports in both ports is positively influenced by the following economic activities:

- Manufacture of leather and related products;

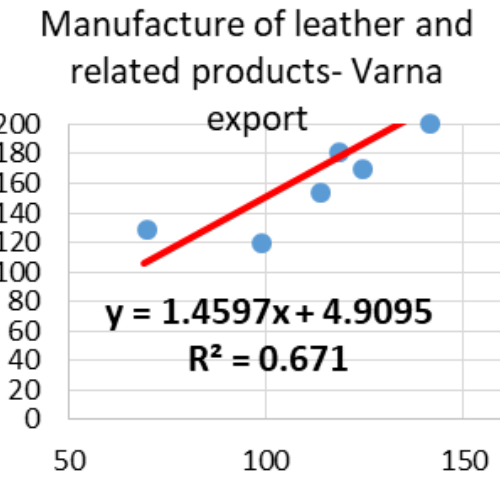

Manufacture of coke and refined petroleum products -

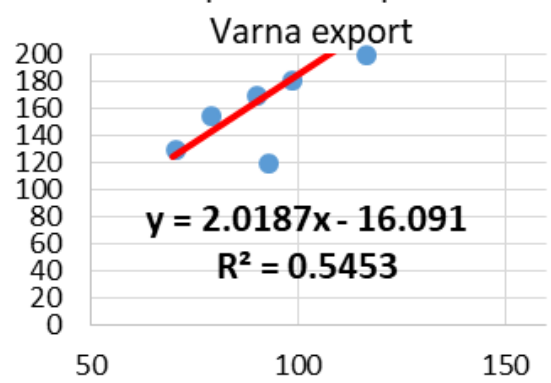

- Manufacture of coke and refined petroleum products;

- Manufacture of basic metals;

- Manufacture of other transport equipment.

The regression models of those dependencies and their equations are presented on Figure 12.

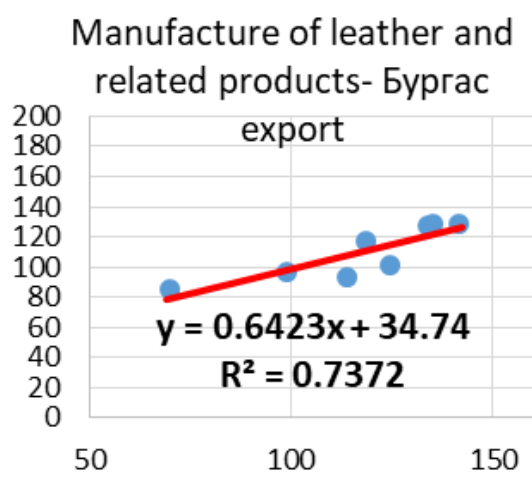

Manufacture of coke and refined petroleum products Бургас export

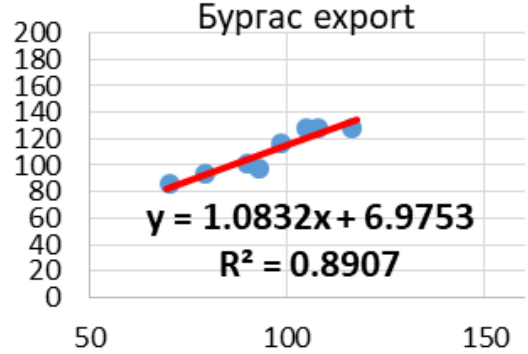

Fig. 13 Regression models of the exports through the Port of Burgas and the Port of Varna and the influence of common factors (Continuation on the next page) 
Manufacture of basic

metals- Varna export

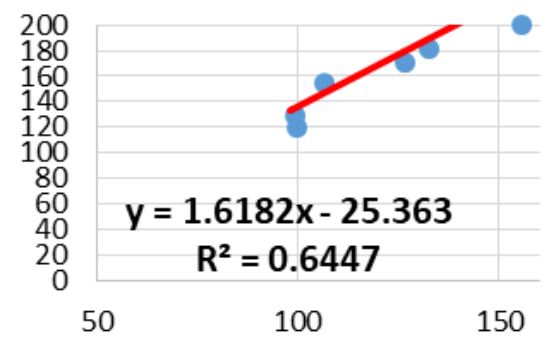

Manufacture of other transport equipment- Varna export

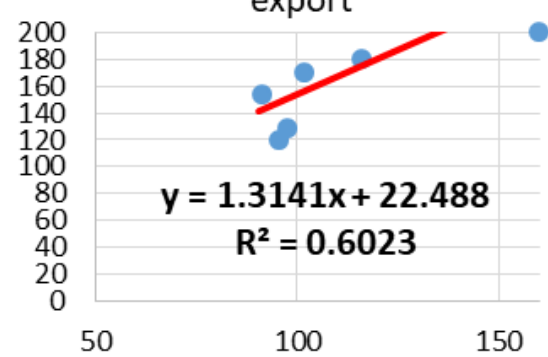

Manufacture of basic metals- Бургас export

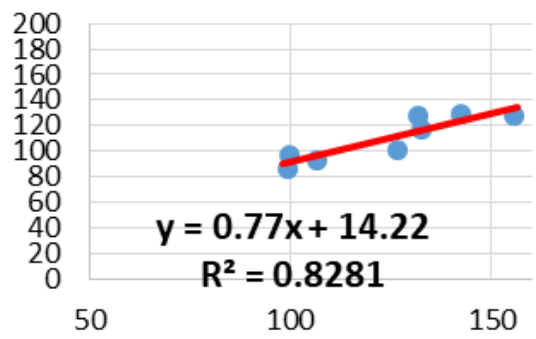

Manufacture of other transport equipment- Burgas export

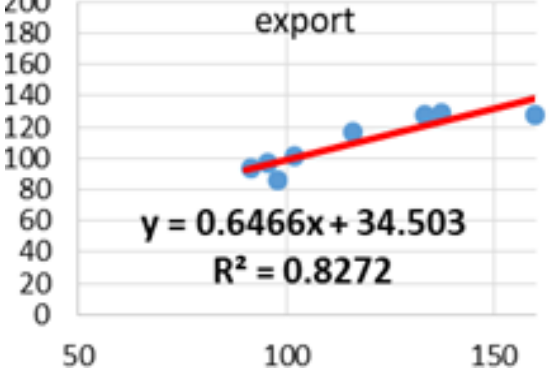

Fig. 14 Regression models of the exports through the Port of Bugas and the Port of Varna and the influence of common factors

Two economic activities with negative influence over the exports freight turnover in the Port of Varna are the following:

- Manufacture of textiles;

Manufacture of textilesVarna export

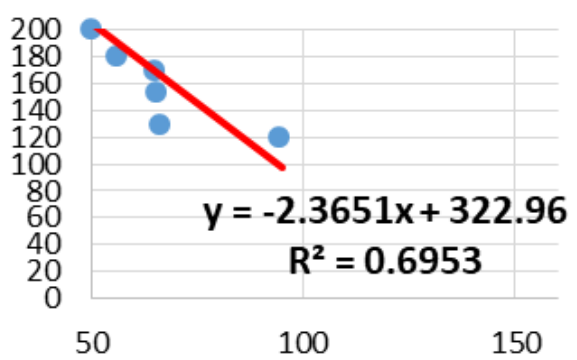

- Manufacture of machinery and equipment n.e.c. The regression models of those dependencies and their equations are presented on Figure 13.

Fig. 15 Regression models of the dependencies between the exports and the significant factor variables for the Port of Varna

The specific factors for the Port of Burgas, influencing the exports freight turnover are presented by three economic activities:

- Manufacture of fabricated metal products, except machinery and equipment;
Manufacture of machinery and equipment n.e.c.- Varna export

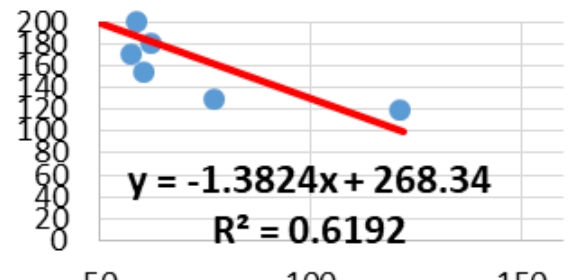

- Manufacture of computer, electronic and optical products;

- Manufacture of electrical equipment.

The regression equations and the models of those dependencies are represented on Figure 14. 

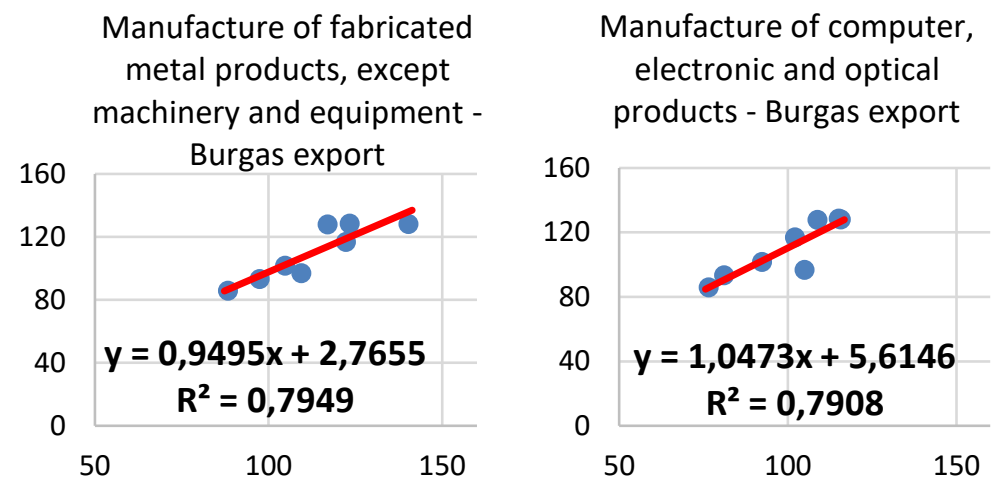

Manufacture of electrical equipment - Burgas export

Fig. 16 Regression models of the dependencies between the exports and the significant factor variables for the Port of Burgas

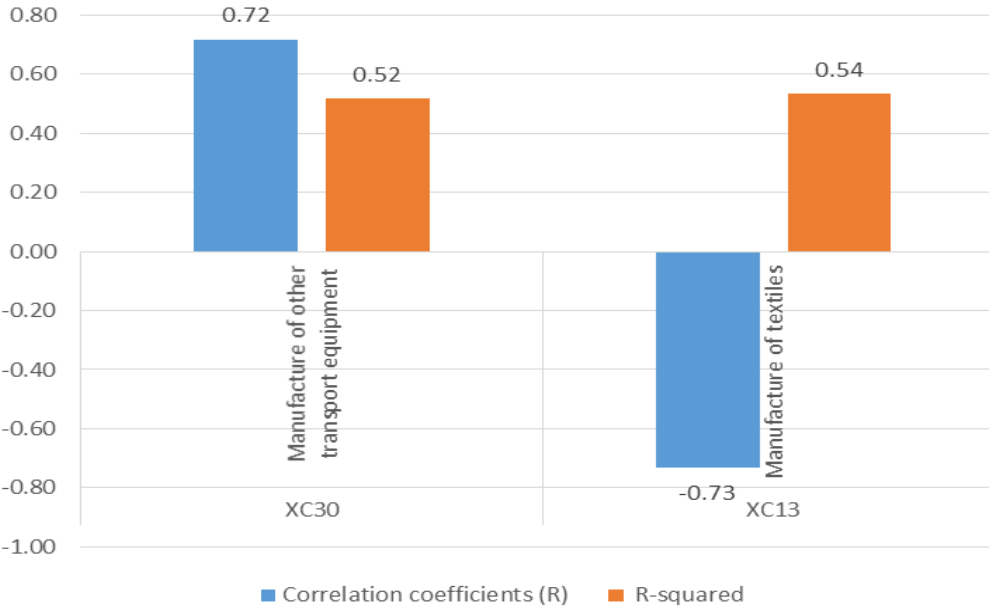

Fig. 17 Statistically significant dependencies for the transit of the Port of Varna

The transit freight turnover through the Port of The economic activity "Manufacture of other Varna is highly influenced by two economic transport equipment" has a positive influence over activities (Figure 15). the transit freight turnover of the Port of Varna.

The economic activity "Manufacture of textiles", There are 5 economic activities, significantly with positive influence over the imports in the Port influencing the level of the transit freight turnover of Varna has approximately the same but negative of the Port of Burgas in negative point of view influence on the transit freight turnover of the port. (Figure 16).

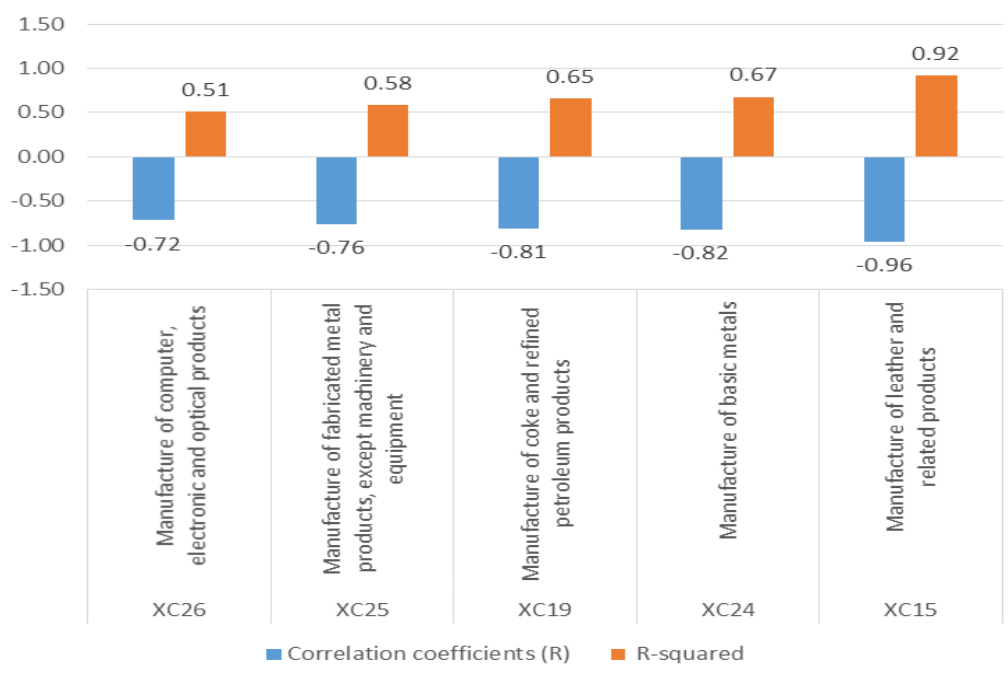

Fig. 18 Statistically significant dependencies for the transit of the Burgas port 
The same factors show positive correlation with the export freight turnover of the Port of Burgas, while the economic activity "Manufacture of computer, electronic and optical products" is influencing positively the levels of imports through the port.

The following three activities are influencing positively the levels of exports through the Port of Varna:
- Manufacture of leather and related products;

- Manufacture of coke and refined petroleum products;

- Manufacture of basic metals.

Summarized by type of freight turnover and direction of the influences of the different economic activities the results are presented in Table 5.

Table 5. Direction of economic activity influence on port freight turnover for imports, exports and transit

\begin{tabular}{|c|c|c|c|c|c|c|c|}
\hline \multirow{3}{*}{\multicolumn{2}{|c|}{ Factor variables (Economic Activities) }} & \multicolumn{6}{|c|}{ Dependent variables } \\
\hline & & \multicolumn{3}{|c|}{ Port Varna } & \multicolumn{3}{|c|}{ Port Burgas } \\
\hline & & import & export & transit & import & export & transit \\
\hline X & Industry total & $\ldots$ & ... & $\ldots$ & +++ & $\ldots$ & $\ldots$ \\
\hline XB & Mining and quarrying & +++ & $\ldots$ & $\ldots$ & $\ldots$ & $\ldots$ & $\ldots$ \\
\hline XB5 & Mining of coal and lignite & ... & $\ldots$ & $\ldots$ & $\ldots$ & $\ldots$ & $\ldots$ \\
\hline XB7 & Mining of metal ores & $\ldots$ & $\ldots$ & $\ldots$ & $\ldots$ & $\ldots$ & $\ldots$ \\
\hline XB8 & Other mining and quarrying & +++ & $\ldots$ & $\ldots$ & +++ & $\ldots$ & $\ldots$ \\
\hline $\mathrm{XC}$ & Manufacturing & +++ & $\ldots$ & $\ldots$ & $\ldots$ & $\ldots$ & $\ldots$ \\
\hline $\mathrm{XC10}$ & Manufacture of food products & $\ldots$ & $\ldots$ & $\ldots$ & $\ldots$ & $\ldots$ & $\ldots$ \\
\hline $\mathrm{XC11}$ & Manufacture of beverages & +++ & $\ldots$ & $\ldots$ & +++ & $\ldots$ & $\ldots$ \\
\hline $\mathrm{XC12}$ & Manufacture of tobacco products & +++ & $\ldots$ & $\ldots$ & $\ldots$ & $\ldots$ & $\ldots$ \\
\hline $\mathrm{XC13}$ & Manufacture of textiles & +++ & -- & --- & $\ldots$ & $\ldots$ & $\ldots$ \\
\hline $\mathrm{XC14}$ & Manufacture of wearing apparel & +++ & $\ldots$ & $\ldots$ & +++ & $\ldots$ & $\ldots$ \\
\hline $\mathrm{XC15}$ & Manufacture of leather and related products & ... & +++ & $\ldots$ & $\ldots$ & +++ & --- \\
\hline $\mathrm{XC16}$ & $\begin{array}{l}\text { Manufacture of wood and of products of wood and cork, } \\
\text { except furniture; manufacture of articles of straw and } \\
\text { plaiting materials }\end{array}$ & $\cdots$ & $\cdots$ & $\cdots$ & $\cdots$ & $\cdots$ & $\cdots$ \\
\hline $\mathrm{XC18}$ & Printing and reproduction of recorded media & +++ & $\ldots$ & $\ldots$ & $\ldots$ & $\ldots$ & $\ldots$ \\
\hline XC19 & Manufacture of coke and refined petroleum products & $\ldots$ & +++ & $\ldots$ & $\ldots$ & +++ & --- \\
\hline XC20 & Manufacture of chemicals and chemical products & $\ldots$ & $\ldots$ & $\ldots$ & +++ & $\ldots$ & $\ldots$ \\
\hline $\mathrm{XC21}$ & $\begin{array}{l}\text { Manufacture of basic pharmaceutical products and } \\
\text { pharmaceutical preparations }\end{array}$ & +++ & $\cdots$ & $\cdots$ & +++ & $\cdots$ & $\cdots$ \\
\hline XC22 & Manufacture of rubber and plastic products & +++ & $\ldots$ & $\ldots$ & $\ldots$ & $\ldots$ & $\ldots$ \\
\hline $\mathrm{XC23}$ & Manufacture of other non-metallic mineral products & $\ldots$ & $\ldots$ & $\ldots$ & +++ & $\ldots$ & $\ldots$ \\
\hline $\mathrm{XC24}$ & Manufacture of basic metals & ... & +++ & $\cdots$ & $\ldots$ & +++ & -- \\
\hline $\mathrm{XC25}$ & $\begin{array}{l}\text { Manufacture of fabricated metal products, except } \\
\text { machinery and equipment }\end{array}$ & $\cdots$ & $\cdots$ & $\cdots$ & $\cdots$ & +++ & --- \\
\hline XC26 & Manufacture of computer, electronic and optical products & $\ldots$ & $\ldots$ & $\ldots$ & +++ & +++ & --- \\
\hline $\mathrm{XC27}$ & Manufacture of electrical equipment & $\ldots$ & $\ldots$ & $\ldots$ & $\ldots$ & +++ & $\ldots$ \\
\hline XC28 & Manufacture of machinery and equipment n.e.c. & +++ & -- & $\cdots$ & $\ldots$ & $\ldots$ & $\ldots$ \\
\hline XC29 & Manufacture of motor vehicles, trailers and semi-trailers & $\ldots$ & $\ldots$ & $\ldots$ & +++ & $\ldots$ & $\ldots$ \\
\hline XC30 & Manufacture of other transport equipment & ... & +++ & +++ & $\ldots$ & +++ & $\ldots$ \\
\hline XC31 & Manufacture of furniture & +++ & $\ldots$ & $\ldots$ & ... & $\ldots$ & $\ldots$ \\
\hline XC32 & Other manufacturing & $\ldots$ & $\cdots$ & $\ldots$ & ... & $\ldots$ & $\ldots$ \\
\hline XC33 & Repair and installation of machinery and equipment & $\ldots$ & $\ldots$ & $\ldots$ & $\ldots$ & $\ldots$ & $\ldots$ \\
\hline
\end{tabular}




\section{CONCLUSIONS}

The results indicate, that all the dependencies between economic activities and the freight turnover of the selected ports, defined as statistically significant have correlation coefficient $\mathrm{R}>|0.7|$ and $\mathrm{R} 2>0.5$.

The research shows, that 23 among the reviewed 29 economic activities have got a statistically significant influence over the freight turnover of the ports and the mutual relations could be adequately represented for the purposes of forecasting by means of uni-factor linear models.

There are no established significant linear links to the freight turnover of the ports for six among the researched economic activities (Mining of coal and lignite; Mining of metal ores; Manufacture of food products; Manufacture of wood and of products of wood and cork, except furniture; Manufacture of articles of straw and plaiting materials; Other manufacturing; Repair and installation of machinery and equipment).

The significant correlations for the imports and exports through the ports are positive, while for the levels of the transit freight turnover the observed correlations with the factor variables are mostly negative.

Eight of the researched economic activities turn to be common factors for both ports. Four of them are influencing the import levels of both ports (Other mining and quarrying; Manufacture of beverages; Manufacture of wearing apparel; Manufacture of basic pharmaceutical products and pharmaceutical preparations) and another four are influencing the export levels (Manufacture of leather and related products, Manufacture of coke and refined petroleum products, Manufacture of basic metals, Manufacture of other transport equipment).

Certain part of the economic activities are negatively or reciprocally influencing the levels of the port freight turnover.

Significant negative influence over the exports levels through the Port of Varna have two economic activities (Manufacture of textiles $n$ Manufacture of machinery and equipment n.e.c.).

The economic activity "Manufacture of textiles" has also a significant negative influence over the transit freight turnover of the Port of Varna.

Significant negative influence over the transit freight turnover of the Port of Burgas have economic activities (Manufacture of leather and related products; Manufacture of coke and refined petroleum products;Manufacture of basic metals; Manufacture of fabricated metal products, except machinery and equipment; Manufacture of computer, electronic and optical products). Simultaneously, these activities have a considerable positive influence over the exports through the Port of Burgas, and the first three are also influencing positively the exports through the Port of Varna.

For both ports, none of the observed economic activities has a significant negative influence over the imports.

For the Port of Burgas, no significant negative influence over the exports is observed on the side of the researched economic activities.

\section{WORKS CITED}

Jelezov, E., \& Kirilova, G. (2017, January 15). Industrial influence on the international freight traffic of the land transports in the Republic of Bulgaria. (Z. Cekerevac, Ed.) MEST Journal, 5(1), 47-56. doi:10.12709/ mest.05.05.01.06

Jelezov, E., \& Kirilova, G. (2015). Impact of the industry in the Republic of Bulgaria on the transport market demand. 20. Medzinarodna vedecka konferencia Riesenie krizovych situacii v specifickom prostredi. Zilina: Fakulta bezpecnostneho inzinierstva ZU.

EC. (2018). Eurostat - Industry, trade, and services. Retrieved from Eurostat: http://ec.europa.eu/eurostat

NSI. (2018). Short-term Business Statistics. Retrieved from National Statistical Institute: http://www.nsi.bg/ en/content/6797/short-term-business-statistics

EC, (2006). Statistical Classification of Economic Activities in the European Community (NACE). Retrieved December 2018 from http://eur-lex.europa.eu/legal-content/EN/TXT/?uri=CELEX: 32006R1893 
Received for publication: 10.01.2018

Revision received: $\quad 09.08 .2018$

Accepted for publication: 27.12.2018

\section{How to cite this article?}

Style - APA Sixth Edition:

Jelezov, E., \& Kirilova, G. (2019, January 15). Economic Activities Influence Models on The Traffic Flows in Bulgarian Seaports. (Z. Čekerevac, Ed.) MEST Journal, 7(1), 21-33. doi:10.12709/mest.07.07.01.04

Style - Chicago Sixteenth Edition:

Jelezov, Emil, and Gergana Kirilova. 2019. "Economic Activities Influence Models on The Traffic Flows in Bulgarian Seaports." Edited by Zoran Čekerevac. MEST Journal (MESTE) 7 (1): 21-33. doi:10.12709/mest.07.07.01.04.

Style - GOST Name Sort:

Jelezov, Emil, and Gergana Kirilova. 2019. "Economic Activities Influence Models on The Traffic Flows in Bulgarian Seaports." Edited by Zoran Čekerevac. MEST Journal (MESTE) 7 (1): 21-33. doi:10.12709/mest.07.07.01.04.

Style - Harvard Anglia:

Jelezov, E. \& Kirilova, G., 2019. Economic Activities Influence Models on The Traffic Flows in Bulgarian Seaports. MEST Journal, 15 January, 7(1), pp. 21-33.

Style - ISO 690 Numerical Reference:

Economic Activities Influence Models on The Traffic Flows in Bulgarian Seaports. Jelezov, Emil and Kirilova, Gergana. [ed.] Zoran Čekerevac. 1, Belgrade - Toronto : MESTE, January 15, 2019, MEST Journal, Vol. 7, pp. 21-33 